\title{
Standardization of Explant Bud Break in Melia dubia - Australian Teak Using Tissue Culture Techniques
}

\author{
R. Aishwarya ${ }^{1}$, V. G. Saravana Kumar ${ }^{2}$ \\ ${ }^{1}$ Student, Department of Biotechnology, St. Michaels College of Engineering and Technology, Kalayarkoil \\ ${ }^{2}$ Associate Professor, Department of Biotechnology, St. Michaels College of Engineering and Technology, Kalayarkoil \\ Corresponding Author: R. Aishwarya
}

\begin{abstract}
Meliadubia is the fast growing multipurpose tree species, Australian Teak wood variety, also called as a Mahaneem or Forest neem, which has a great demand in Wood industry. The harvesting period is 6-7 years unlike the commercial Burma teak wook variety Tectonagrandis which takes almost a generation (60-70 years). Moreover, the Australian teak wood is cheaper when compared to Burma Teak wood. Conventional growth of Meliadubia through seeds is not much successful where the germination rate is very poor of about 14-34\% only. So, Invitro propagation of the Meliadubia is very essential for large scale propagation of the species which also possess therapeutic properties. Also, Meliadubia can generate substantial power, the yellow mature stem, with more fibre and lignin content yielded around 200 dry metric tonnes per hectare. This study is aimed at the Standardization of Initiation stage of Meliadubia explants through Invitro propagation. Comparison of best combination of growth regulator was identified. The developed hardened sapling through Invtro propagation can be harvested in 5 years which then will be useful for various purposes. Through this technique, the mass propagation is simple and effective, propagated plant will be like mother who is identified the best and disease free.
\end{abstract}

Keywords: Meliadubia, Invitro propagation, Initiation, Mass propagation

\section{Introduction}

Meliadubia is a good energy source crop which allows more diversity than bamboo species. It is commonly found in the hills. It provides a rapid growth. The extract from different parts of the Meliadubia plant possess antiviral, antibacterial, antifungal, antidiabetic, antineoplastic, antihelmintic and antileprosy properties. Conventionally, M. dubiais propagated through seeds, which have very poor (14\%-34.3\%) germination rates because of its hard stony eed coat, which makes it difficult to germinate without any treatment (Anand et al., 2012).The combined juice of papaya leaf, malaivembu or hill neem and common neem has been a daily dose for dengue patients for getting rid of the disease (Anand B et al., 2012).

\section{Demand for Meliadubia}

It is a fast growing multipurpose tree species, which has high demand in plywood industry, termite and fungal resistant timber and has potential to use in biomass power plants (power generation) (Batcher M.S). Meliadubia through conventional propagation using seeds has limited viability period. Fruits mature on tree, but do not drop and cling to the branches and loose viability on the tree itself. Farmers use wilding and raise bund planting of $M$. dubia. Therefore, production of planting material of $M$. dubiahas become a problem (Apichart Kaosaard, et la., 1998).

\section{Need for Invitro Propagation}

Meliadubia is one of the fast growing tree and give good returns. It can be used in collection of biomass or plywood industries. After 3 years, 30-40 tons of biomass/acre can be harvested up to 10 years. Up to 5 years, ground nut, chilli, turmeric, blackgram as inter crops can be cultivated.
Meliadubia has nutritive value in leaves which when fed by sheep, goats possess more nutritive value. In addition, the extract from different parts of the $M$. dubia plant are known to have antiviral, antibacterial, antifungal, antidiabetic, antineoplastic, antihelmintic and antileprosy properties. For this reason $M$. dubia trees growing naturally have been indiscriminately logged and resulted in significant decline in its population. Therefore, it is imperative to use plant tissue culture method for large scale production of clonal plantingmaterial of the species from superiorgeno types for quick rejuvenation (Baskaran P, Jayabalan N, 2008).

\section{Materials and Methods}

\section{Preparation of Explants}

The living parts of the plant are referred as explants which are responsible for the development of a whole plant. Healthy mature 3 year old Meliadubia plant was procured. The nodes and young leaves as explants were collected from the plants. The collected explants were brought to the production laboratory and washed thoroughly in running tap water for $10 \mathrm{~min}$ in order to eliminate the muddy/unwanted particles from the explants. Excision of nodal explants of about $1-1.5 \mathrm{~cm}$ was done with the help of secateurs whereas leaf discs were prepared (Bhimi Ram et al., 2012).

\section{Explants Sterilization}

The Nodal explants were soaked in antifungal and antibacterial solution containing carbendazim $(0.1 \%)$ and streptocycline $(0.1 \%)$ for 15 minutes. The sterilization is followed by the treatment of detergent, Polysorbate-20 for 20 minutes. The explants were washed with sterile water 


\section{International Journal of Science and Research (IJSR) \\ ISSN (Online): 2319-7064}

Index Copernicus Value (2013): 6.14 | Impact Factor (2015): 6.391

three times to ensure the complete wash of detergent. The sterilization is further carried out inside laminar air flow chamber; explants were treated with Ethanol $(70 \%)$ for 30 sec and Mercuric chloride (0.1\%) spanned for $8,9,10,11$, $12 \mathrm{~min}$. The explants were removed from the mercuric chloride solution and washed with sterile water 3 times to eliminate the toxic effects of Mercuric chloride (Bhimi Ram et al).

The tender leaves as explants were soaked in antifungal and antibacterial solution containing carbendazim $(0.1 \%)$ and streptocycline $(0.1 \%)$ for 15 minutes. The sterilization is followed by the treatment of detergent, Polysorbate-20 for 15-20 minutes (Bonner J. and Devirian P.S, 1999). The explants were washed with sterile water three times to ensure the complete wash of detergent. The sterilization is further carried out inside laminar air flow chamber; explants were treated with Ethanol $(70 \%)$ for 30 seconds and Mercuric chloride $(0.1 \%)$ spanned for 3, 5, 7, 10min. The explants were removed from the mercuric chloride solution and washed with sterile water 3 times to eliminate the toxic effects of Mercuric chloride (Biswas $\mathrm{K}$ et al., 2002).

The Mortality rate was calculated by

$\%$ Mortality $=$ Explants contaminated $\times 100$ Total no of Explants

\section{Explants Initiation}

Initiation stage begins with the emergence of shoots using nodes whereas occurrence of callus induction will be therefore leaves. In leaves, callus regeneration was observed in 60 days which is referred as Indirect organogenesis whereas in nodes, Direct organogenesis was observed which gave raise to shoot formation in 15 days.

The surface sterilized explants were inoculated in following MS basal media treatments + Sucrose 3\% with various growth regulator concentrations (Bonner J. and Addicott F, 1997).

\section{Nodes Leaves}

Table 1: Initiation Media for the Nodes and Leaves

\begin{tabular}{|c|c|c|c|}
\hline MEDIA & $\begin{array}{c}\text { 6BAP+NAA } \\
\text { COMBINATION } \\
(\mathrm{mg} / \mathrm{l})\end{array}$ & MEDIA & $\begin{array}{c}\text { 6BAP } \\
\text { TRIALS } \\
(\mathrm{mg} / \mathrm{l})\end{array}$ \\
\hline N1 & $0.5+0.1$ & L1 & 0.1 \\
\hline N2 & $1+0.1$ & L2 & 0.2 \\
\hline N3 & $1.5+0.1$ & L3 & 0.3 \\
\hline N4 & $2+0.1$ & L4 & 0.4 \\
\hline N5 & $0.5+0.2$ & L5 & 0.5 \\
\hline N6 & $1+0.2$ & L6 & 0.6 \\
\hline N7 & $1.5+0.2$ & L7 & 0.7 \\
\hline N8 & $2+0.2$ & L8 & 0.8 \\
\hline & & L9 & 0.9 \\
\cline { 2 - 4 } & & L10 & 1 \\
\hline
\end{tabular}

The explants were placed in upright position on each treatment. The inoculated jars were incubated.

\section{Culture Conditions}

The Nodal explants were subjected to light for $10-12 \mathrm{~h}$ in the growth room after 2 days of darkness. Initiated leaves were placed under light intensity for 10-12 $\mathrm{h}$ in the growth room. Photoperiod provided by cool white fluorescent lamps of 1500-3000 lux, temperature of about $25 \pm 2{ }^{\circ} \mathrm{C}$ and humidity of $35-40 \%$. The observation for the callus induction and shoot formation was observed often.

\section{Results and Discussion}

\section{Nodal Explant Sterilization:}

Table 2: Surface Sterilization with Nodes

\begin{tabular}{|c|c|c|c|c|}
\hline Treatment & $\begin{array}{c}\text { No Of } \\
\text { Explants } \\
\text { Taken }\end{array}$ & $\begin{array}{c}\text { Non- } \\
\text { Responsive } \\
\text { Explants }\end{array}$ & $\begin{array}{c}\text { Response } \\
(\%)\end{array}$ & $\begin{array}{c}\text { Mean Rate Of } \\
\text { Shoot } \\
\text { Regeneration } \\
(\%)\end{array}$ \\
\hline $\begin{array}{c}0.1 \% \mathrm{HgCl}_{2} \\
-8 \mathrm{~min}\end{array}$ & & 23 & 8 & 89 \\
\hline $\begin{array}{c}0.1 \% \mathrm{HgCl}_{2} \\
-9 \mathrm{~min}\end{array}$ & \multirow{2}{*}{25} & 20 & 20 & 81 \\
\hline $\begin{array}{c}0.1 \% \mathrm{HgCl}_{2} \\
-10 \mathrm{~min}\end{array}$ & 1 & 96 & 77 \\
\hline $\begin{array}{c}0.1 \% \mathrm{HgCl}_{2} \\
-11 \mathrm{~min}_{n}\end{array}$ & 15 & 40 & 62 \\
\hline $\begin{array}{c}0.1 \% \mathrm{HgCl}_{2} \\
-12 \mathrm{~min}\end{array}$ & & 13 & 48 & 58 \\
\cline { 3 - 5 } & & & & \\
\hline
\end{tabular}

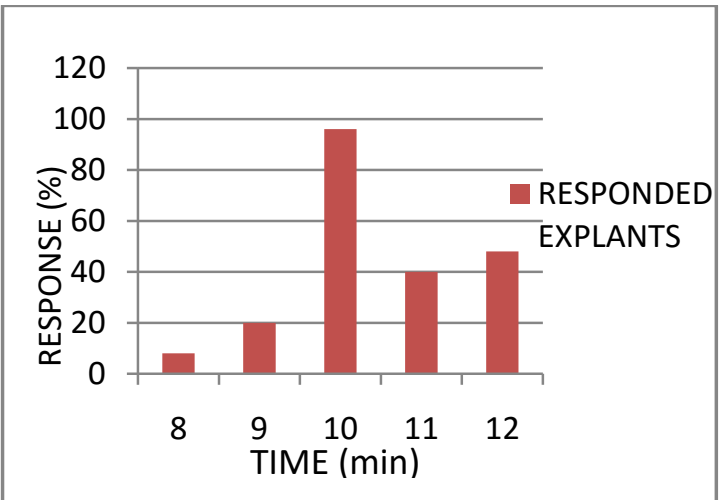

(i)

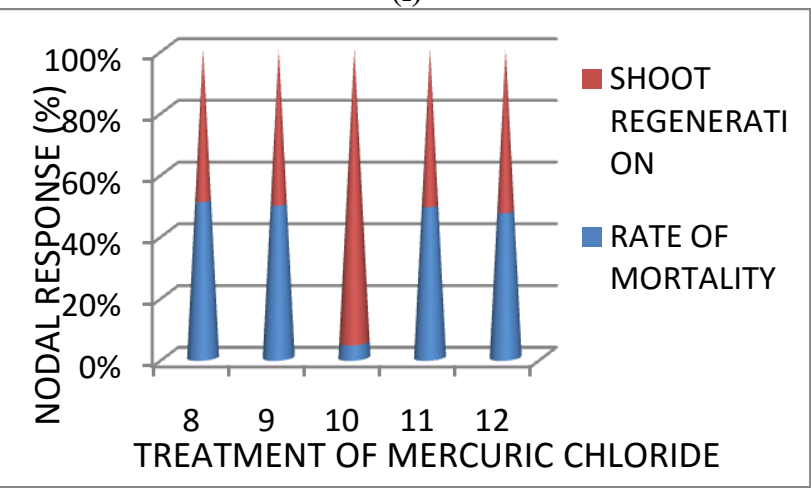

(ii)

Graph 1: (i) Graph showing Shoot generation response by nodal explants (ii) Graph showing Rate of Mortality with shoot regeneration

Majority of the explants survived after treatment when they were exposed to mercuric chloride for about $10 \mathrm{~min}$. Treatment less than $10 \mathrm{~min}$ were found with more mortality of the explants whereas treatment for more than $10 \mathrm{~min}$ found to have mortality but comparatively less.

\section{Volume 5 Issue 6, June 2016}




\section{International Journal of Science and Research (IJSR) \\ ISSN (Online): 2319-7064}

Index Copernicus Value (2013): 6.14 | Impact Factor (2015): 6.391

Rate of shoot generation was found as $77 \%$ whereas $89 \%$ of shoot regeneration was noted in 8 min treatment with mortality rate of $92 \%$. At $10 \mathrm{~min}$, the rate of mortality was found to be lesser and rate of shoot regeneration was moderate when compared to other treatments which showed almost equal mortality rate and shoot regeneration.

\section{Leaves Sterilization}

Table 3: Surface Sterilization with Leaves

\begin{tabular}{|c|c|c|c|c|}
\hline Treatment & $\begin{array}{c}\text { No Of } \\
\text { Explants } \\
\text { Taken }\end{array}$ & $\begin{array}{c}\text { Non- } \\
\text { Responsive } \\
\text { Explants }\end{array}$ & $\begin{array}{c}\text { Response } \\
(\%)\end{array}$ & $\begin{array}{c}\text { Mean Rate } \\
\text { Of Callus } \\
\text { Induction } \\
(\%)\end{array}$ \\
\hline $\begin{array}{c}0.1 \% \mathrm{HgCl}_{2} \\
-3 \mathrm{~min}\end{array}$ & & 24 & 4 & 95 \\
\hline $\begin{array}{c}0.1 \% \mathrm{HgCl}_{2} \\
-5 \mathrm{~min}\end{array}$ & \multirow{2}{*}{25} & 2 & 92 & 86 \\
\hline $\begin{array}{c}0.1 \% \mathrm{HgCl}_{2} \\
-7 \mathrm{~min}\end{array}$ & & 19 & 24 & 80 \\
\hline $\begin{array}{c}0.1 \% \mathrm{HgCl}_{2} \\
-9 \mathrm{~min}\end{array}$ & & 16 & 36 & 69 \\
\hline $\begin{array}{c}0.1 \% \mathrm{HgCl}_{2} \\
-10 \mathrm{~min}\end{array}$ & & 15 & 40 & 62 \\
\hline
\end{tabular}

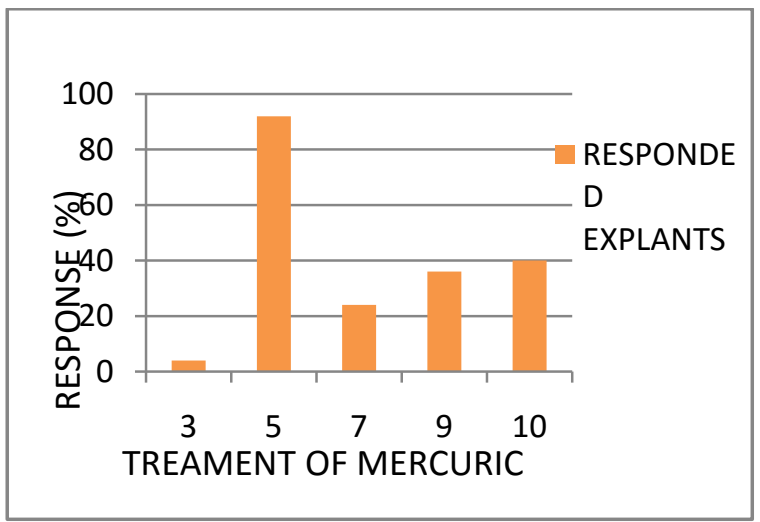

(i)

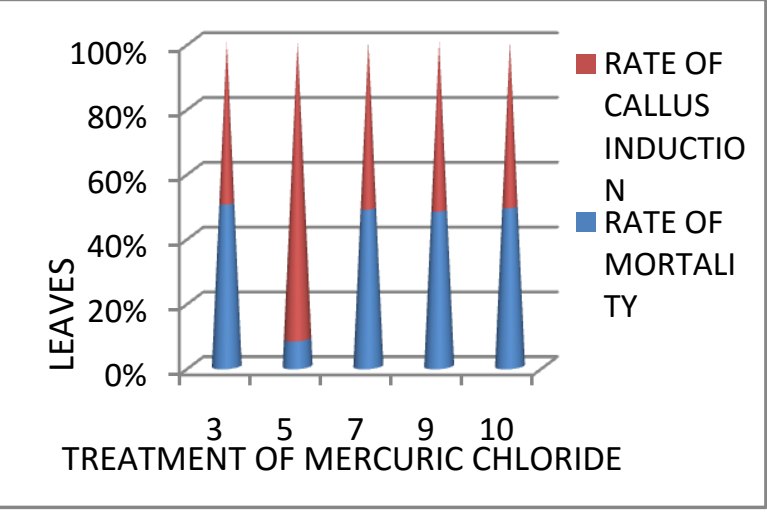

(ii)

Graph 2: (i) Graph showing callus induction response by Leaves explants (ii) Graph showing Rate of Mortality with callus induction

Majority of the leaves explants survived after treatment when they were exposed to mercuric chloride for about 5 min. Other treatments were found with high mortality of the explants. Rate of callus induction was found as $86 \%$ when treated with $5 \mathrm{~min}$, whereas $95 \%$ of callus induction was noted in 3 min treatment with mortality rate of $96 \%$. At $5 \mathrm{~min}$, the rate of mortality was found to be lesser and rate of callus induction was moderate when compared to other treatments which showed almost equal mortality rate and callus induction.

\section{Initiation in Nodes}

Table 4: Initiation Response in Nodes

\begin{tabular}{|c|c|c|c|c|}
\hline $\begin{array}{c}\text { Trial } \\
\text { Media }\end{array}$ & $\begin{array}{c}\text { No Of } \\
\text { Survived } \\
\text { Explants } \\
\text { Taken }\end{array}$ & $\begin{array}{c}\text { No Of } \\
\text { Explants } \\
\text { Raised } \\
\text { Shoots }\end{array}$ & $\begin{array}{c}\text { Mean } \\
\text { Height Of } \\
\text { Shoots } \\
(\text { Cm })\end{array}$ & $\begin{array}{c}\% \text { Initiation } \\
\text { Response }\end{array}$ \\
\hline N1 & \multirow{8}{*}{20} & 6.3 & 0.77 & 31.5 \\
\hline N2 & & 11.6 & 1.2 & 58 \\
\hline N3 & & 16.4 & 1.6 & 82.5 \\
\hline N4 & & 18.5 & 2.3 & 93 \\
\hline N5 & & 12 & 1.24 & 60 \\
\hline N6 & & 10 & 1.08 & 50 \\
\hline N7 & & 8.7 & 0.93 & 43.5 \\
\hline N8 & & 5.3 & 0.56 & 26.5 \\
\hline
\end{tabular}

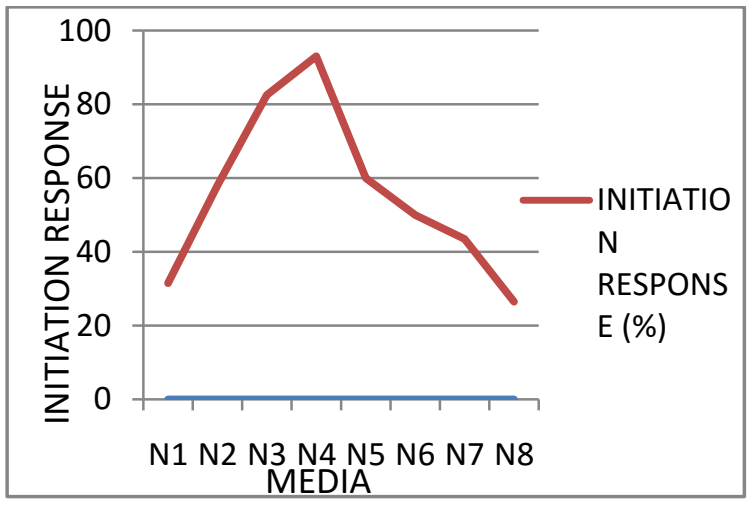

(i)

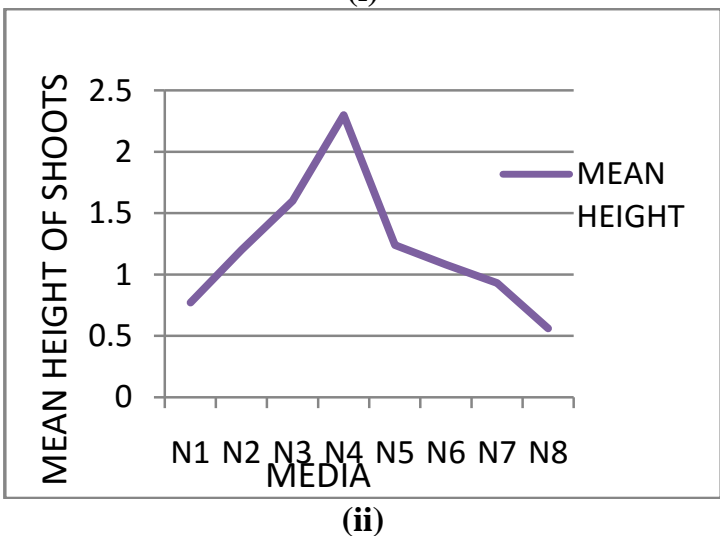

Graph 3: (i) Graph showing Initiation response in Nodes (ii) Graph showing the Mean height of the shoots in Nodes Figure 1: (a) Initiation of Nodes - Day 1 (b) Initiation of Nodes - Day 14 (c) Initiation of Nodes - Day 28 


\section{International Journal of Science and Research (IJSR) \\ ISSN (Online): 2319-7064}

Index Copernicus Value (2013): 6.14 | Impact Factor (2015): 6.391

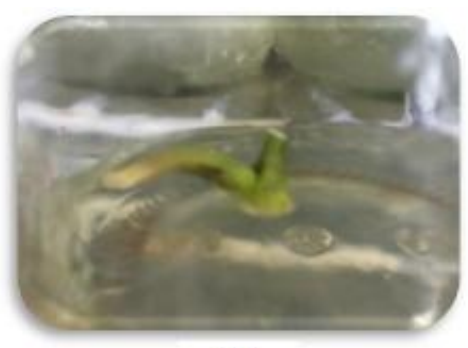

(a)

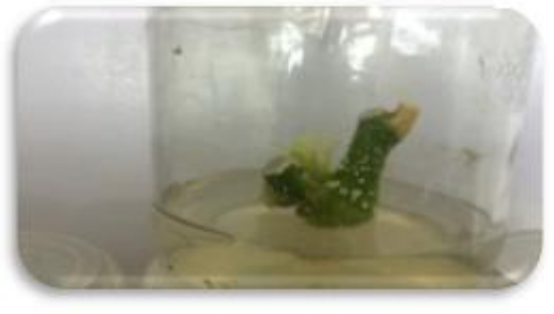

(b)

Initiation of nodal response was found as $93 \%$ which trailed with the combination of $6 \mathrm{BAP}+\mathrm{NAA}=2 \mathrm{mg} / \mathrm{l}+$ $0.1 \mathrm{mg} / 1$ with mean height of $2.3 \mathrm{~cm}$. other media trials with 6 BAP and NAA of about $1,3,4,5 \mathrm{mg} / \mathrm{l}$ and $0.2 \mathrm{mg} / \mathrm{l}$ were found with lesser shoot regeneration and less shoot height which was further transferred to multiplication stage.

\section{Initiation in Leaves}

Table 5: Initiation Response in Leaves

\begin{tabular}{|c|c|c|c|c|}
\hline $\begin{array}{c}\text { Trial } \\
\text { Media }\end{array}$ & $\begin{array}{c}\text { No Of } \\
\text { Survived } \\
\text { Explants } \\
\text { Taken }\end{array}$ & $\begin{array}{c}\text { No Of } \\
\text { Explants } \\
\text { Raised } \\
\text { Shoots }\end{array}$ & $\begin{array}{c}\text { Mean } \\
\text { Height Of } \\
\text { Shoots } \\
(\mathrm{cm})\end{array}$ & $\begin{array}{c}\text { Mean } \\
\text { Initiation } \\
\text { Response } \\
(\%)\end{array}$ \\
\hline L1 & \multirow{10}{*}{20} & 6 & 0.4 & 30.3 \\
\hline L2 & & 8 & 0.91 & 42 \\
\hline L3 & & 9 & 1.12 & 56 \\
\hline L4 & & 9 & 1.32 & 65.3 \\
\hline L5 & & 11 & 1.67 & 72 \\
\hline L6 & & 10 & 1.64 & 76 \\
\hline L7 & & 13 & 1.76 & 79.8 \\
\hline L8 & & 13 & 1.83 & 80 \\
\hline L9 & & 14 & 1.89 & 85.5 \\
\hline L10 & & 17 & 2.16 & 90.8 \\
\hline
\end{tabular}

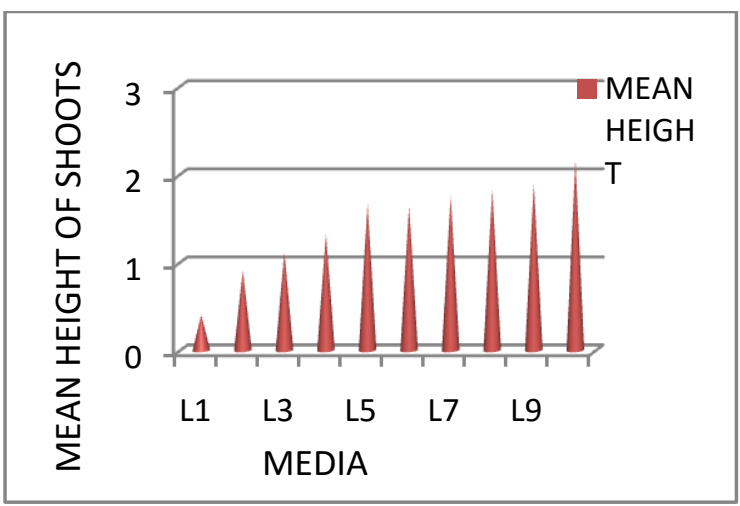

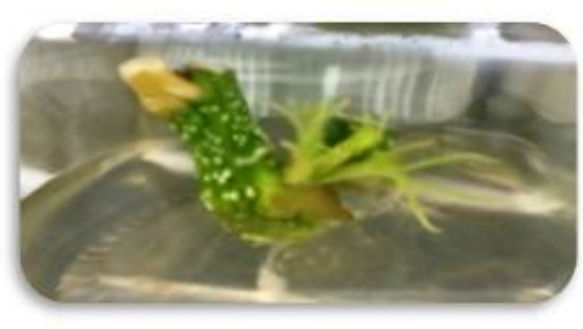

(c)

(i)

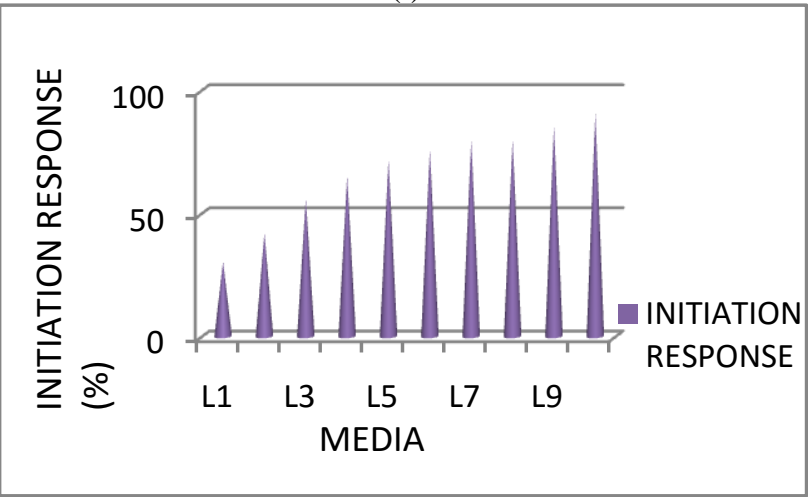

(ii)

Graph 4: (i) Graph showing Mean Height of shoots from Callus (ii) Graph showing the Initiation response from Callus

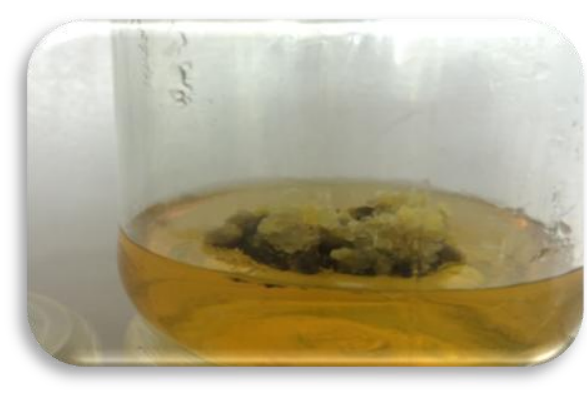

(a)

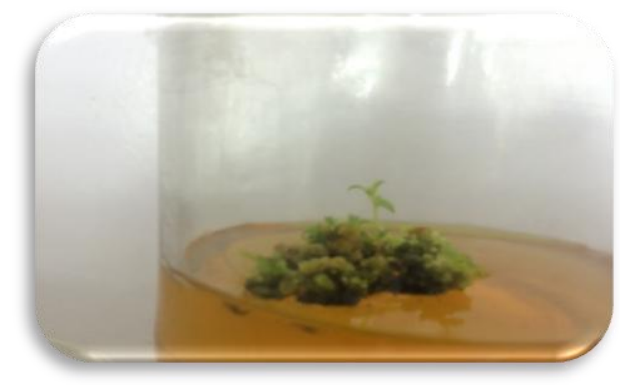

(b)

Figure 2: (a) Initiation of Nodes - Day 14 (b) Initiation of Nodes - Day 28

Volume 5 Issue 6, June 2016 www.ijsr.net 


\section{International Journal of Science and Research (IJSR) \\ ISSN (Online): 2319-7064}

Index Copernicus Value (2013): 6.14 | Impact Factor (2015): 6.391

Initiation of shoot response using leaves as explants was found as $90.8 \%$ which trailed with the combination of $6 \mathrm{BAP}=1 \mathrm{mg} / \mathrm{l}$ with mean shoot height of $2.16 \mathrm{~cm}$ from the undifferentiated mass. Other media trials with 6BAP of about $0.1,0.2,0.3,0.4,0.5, .6,0.7,0.8,0.9 \mathrm{mg} / 1$ were found with lesser callus induction and less shoot height which was further transferred to multiplication stage.

\section{Discussion}

In the present study, Meliadubia was selected as target plants which possess medicinal values as it is as equal as Tectonagrandis which can be used in plywood industry. The explants such as nodes and leaves which undergone various sterilization trials. Majority of the explants survived after treatment when they were exposed to mercuric chloride for about $10 \mathrm{~min}$. Rate of shoot generation was found as $77 \%$ whereas $89 \%$ of shoot regeneration was noted in $8 \mathrm{~min}$ treatment with mortality rate of $92 \%$. At $10 \mathrm{~min}$, the rate of mortality was found to be lesser and rate of shoot regeneration was moderate when compared to other treatments which showed almost equal mortality rate and shoot regeneration. Majority of the leaves explants survived after treatment when they were exposed to mercuric chloride for about $5 \mathrm{~min}$. Rate of callus induction was found as $86 \%$ when treated with 5 min, whereas $95 \%$ of callus induction was noted in $3 \mathrm{~min}$ treatment with mortality rate of $96 \%$. At $5 \mathrm{~min}$, the rate of mortality was found to be lesser and rate of callus induction was moderate when compared to other treatments which showed almost equal mortality rate and callus induction. Initiation of nodal response was found as $93 \%$ which trailed with the combination of $6 \mathrm{BAP}+\mathrm{NAA}=$ $2 \mathrm{mg} / \mathrm{l}+0.1 \mathrm{mg} / \mathrm{l}$ with mean height of $2.3 \mathrm{~cm}$. Response of callus induction in leaves was found as $90.8 \%$ which trailed with the combination of $6 \mathrm{BAP}+\mathrm{NAA}=1 \mathrm{mg} / \mathrm{l}+$ $0.1 \mathrm{mg} / \mathrm{l}$ with mean shoot height of $2.16 \mathrm{~cm}$ from the undifferentiated mass.

\section{Conclusion}

Direct organogenesis was achieved for nodes and indirect organogenesis was done through leaves where undifferentiated mass called callus was formed and led to the formation of shoots. Mortality rate was lesser in Nodal explants whereas response was higher in leaves. Nodes performed best when compared to leaves which were developed by direct organogenesis.

\section{Acknowledgement}

We would like to thank Dr. V. PALANI, MD, Genewin Biotech for giving an opportunity to work in their lab and Mrs. MANASA SATHEESH, CTO, Genewin Biotech, Hosur for the technical guidance and continuous support throughout the work.

\section{References}

[1] Anand B., Devagiri G.M., Maruti G., Vasudev H.S., Khaple A.K., "Effects of Pre-sowing Seed Treatments on Germination and Seedling Growth
Performance of Meliadubia CAV: An Important Multipurpose Tree", International Journal of Life Sciences, 1, 59-63, 2012.

[2] ApichartKaosaard, Verapong Suangtho and Erik D. Kjax, "Genetic Improvement Of Teak (Tectona Grandis) In Thailand", Forest Genetic Resources No. 26, 456-463, 1998.

[3] Baskaran P, Jayabalan N, "Effectof growth regulators on rapid micropropagation and psoralen production in Psoraleacorylifolia", Acta Physiological Plant Sciences, 30, 345-351, 2008.

[4] Batcher M.S., "Element Stewardship Abstract for Meliaazedarach", The Nature Conservancy, Arlington, USA, 7, 678-682.

[5] Bhimi Ram, Trilok Singh Rathore, Gillela Ravi Shankar Reddy, "In vitro propagation of MeliadubiaCav. from seedling explants", Biotechnology Bioinformaticsand Bioengineering, 2(1), 610-616, 2012.

[6] Bhimi Ram, Trilok Singh Rathore and BeenaDerajiraBopanna, "An efficient protocol for micropropagation and genetic stability analysis ofMeliadubiaCav. - an important multipurpose tree", International Journal of Current Microbiology and Applied Sciences, 3(7), 533-544.

[7] Biswas K., Chattopadhyay, Ishita, Banerjee R. K., Bandyopadhyay, Uday., "Biological activities and medicinal properties of neem (Azadirachtaindica)", Current science, 82, 1336-1345, 2002.

[8] Bonner J. and Addicott F., "Cultivation In Vitro Of Excised Pea Roots”, Botany, 99, 144-170, 10, 1997.

[9] Bonner J. and Devirian P.S., "Growth Factor Requirements Of Four Species Of Isolated Roots", American Journal of Botanical Sciences, 26, 661665,1999 